\title{
SUSTAINABLE DEVELOPMENT OF AGRICULTURAL PRODUCERS IS A CONDITION FOR THEIR SUCCESSFUL FUNCTIONING IN THE WORLD MARKET
}

\author{
Hanna Fedosieieva ${ }^{1}$
}

\begin{abstract}
Purpose. Substantiation of a holistic system of goals of steady development of agricultural producers on the conditions of their successful functioning in the world market taking into account global and local trends in the development of the world economy, peculiarities of agricultural activity in Ukraine, and directions of development of the world agricultural market. The methodology of research. The reliability of the study is due to the use of an integrated approach and a significant set of research methods, in particular: systematic approach in studying the connections between phenomena and processes in the system of formation of a holistic system of steady development of agricultural producers on the conditions of their successful functioning in the world market; monographic - for a comprehensive and in-depth study of the peculiarities of the modern manifestation of the key factors of sustainable development of agricultural producers, provided that they operate in the world market; dialectical and abstract-logical - when conducting theoretical generalizations and forming conclusions; the method of scientific abstraction - with a selection of key factors that determine the steady development of agricultural producers; etc. Findings. Considered the main goals of sustainable development on the basis of values, principles, and key factors of the development of the world economy. Determined the main global tendencies of development of the world agricultural market. On the basis of the study, an integrated system of goals for the steady development of agricultural producers in the conditions of their functioning in the world market has been formed. It is noted that the basis of the sustainable development of any system is a combination of economic development with a minimal negative impact on the environment and the socialization of newly created economic transformations. Originality. The integrated system of goals of steady development of agricultural producers in the world market, which includes three interconnected blocks: economic, social and ecological, for which each priority is defined, is substantiated. The main conditions for achieving these goals are presented. Practical implications. The obtained results can be used in substantiating directions of the formation of stable competitive advantages of agricultural producers in the world market.
\end{abstract}

Key words: sustainable development of agricultural producers, world market, agricultural productivity, profitability of agricultural activity, social development, ecological development, innovative technologies.

JEL Classification: Q17, D92, Q50

\section{Introduction}

The United Nations Millennium Declaration, adopted in 2000 by the 189 countries at the UN Millennium Summit, defined the Millennium Development Goals, a comprehensive framework of values, principles, and key development drivers by 2015. In September 2015, in the framework of the 70th session of the UN General Assembly in New York, the United Nations Summit on Sustainable Development, and the adoption of the Agenda for Development after 2015, which approved new development benchmarks, took place. The final document of the Summit "Transforming our world: the 2030 Agenda for Sustainable Development" approved 17 Sustainable Development Goals and 169 Objectives. More than 800 leading experts in the thematic areas of sustainable development have been involved in adapting identified goals and objectives in Ukraine. Representatives of ministries and agencies, government agencies, UN agencies in Ukraine, international organizations, the business community, expert community, public organizations (primarily those representing the interests of the most vulnerable groups), and civil society represented the proposals for sustainable development of Ukraine. This work was supported by all UN agencies in Ukraine, the United Nations Development Program in Ukraine,

Corresponding author:

${ }^{1}$ Mykolayiv National Agrarian University, Ukraine.

E-mail: timofany@ukr.net 
the Green Economy Program implemented by the German Society for International Cooperation on behalf of the Federal Ministry for Economic Cooperation and Development of Germany and jointly with the Institute of Demography and Social Studies named after M. V. Ptukha, National Academy of Sciences of Ukraine. As a result of this work, the goals of sustainable development of Ukraine in four directions were identified: fair social development; sustainable economic growth and employment; effective management; environmental balance and sustainability. The public vision of Ukraine's development until 2030 includes such benchmarks for achieving as the welfare and health of the population, which will be provided by the innovative development of the economy, built on the sustainable use of natural resources. The structure of exports envisages changes aimed at shifting from raw materials and products of primary processing to high value-added products and services. Economic growth should be based on the green economy model. Thanks to energy saving measures and the use of energy efficient practices, the energy intensity of the gross domestic product should be substantially reduced.

Concerning agriculture, the national goals of the sustainable development of Ukraine in this direction are determined by: increasing the productivity of agriculture twice, first of all, due to the use of innovative technologies; ensuring the establishment of sustainable food production systems that contribute to the conservation of ecosystems and gradually improve the quality of land and soils, primarily through the use of innovative technologies; the restoration of degraded lands and soils with the use of innovative technologies; reduction of food loss in production and supply chains. In addition to the aforementioned, the Ministry of Economic Development and Trade of Ukraine has developed a number of tasks, which should be carried out according to the types of economic activity (to create financial and institutional systems that will ensure the development of scientific research and scientific and technical development). In addition, specific tasks relate to the rural population (increase the level of employment, provide access to vocational education, ensure access to social services), infrastructure provision of rural life (to develop a high-quality, reliable, sustainable, and accessible infrastructure based on the use of innovative technologies) and other.

The objective of the work is to substantiate the integral system of tasks of sustainable development of agricultural producers in the conditions of their functioning in the world market taking into account global and local trends of world economic development, peculiarities of agricultural activity in Ukraine, and directions of development of the world market for agricultural products.

\section{The system of sustainable development of agricultural producers}

The globalization of the world economy has led to the emergence and rapid development of the following processes: a violation of the stability of metabolic processes in the biosphere due to manmade and anthropogenic burden; world food problem; stimulation of ecologization of agricultural production and increase of demand for organic agricultural products in the developed countries of the world; increase of world volumes of production of genetically modified agricultural products; annual reduction of world land (including agricultural land) and water resources; rapid development of bio- and energy-efficient technologies, etc. The identified processes directly affect the trends of world trade in agricultural products.

Thus, taking into account the identified goals of sustainable development at the international and national levels, as well as globalization processes in the world and their impact on the development of the world agricultural market, we have identified the system of sustainable development of agricultural producers in the conditions of their functioning in the world market, Figure 1.

Sustainable development of agricultural producers in the conditions of their functioning in the world market should include three interconnected components: economic, ecological, and social one. After all, the basis of the sustainable development of any system is a combination of economic development with a minimal negative impact on the environment and the socialization of newly created economic transformations. In general, achievement of certain goals can be achieved at the expense of innovative development of agricultural commodity producers and a balanced state social and economic policy in the field of agriculture.

The block of economic goals of the sustainable development of agricultural producers in the conditions of their functioning in the world market is quite extensive, it is determined by the peculiarity of the development of certain branches of agriculture, the location of agricultural producers, the level of their logistical support, the size of certain agricultural enterprises, the orientation to a greater extent on internal or external market and other factors. In addition, the realization of the economic goals of sustainable development directly affects the resolution of social and environmental issues in rural areas.

\section{The economic component of ensuring the sustainable development of agricultural producers}

In general, the basis for solving the problem of the sustainability of the development of agricultural commodity producers, including, in the conditions of their functioning in the world market, is the solving of the following tasks: 


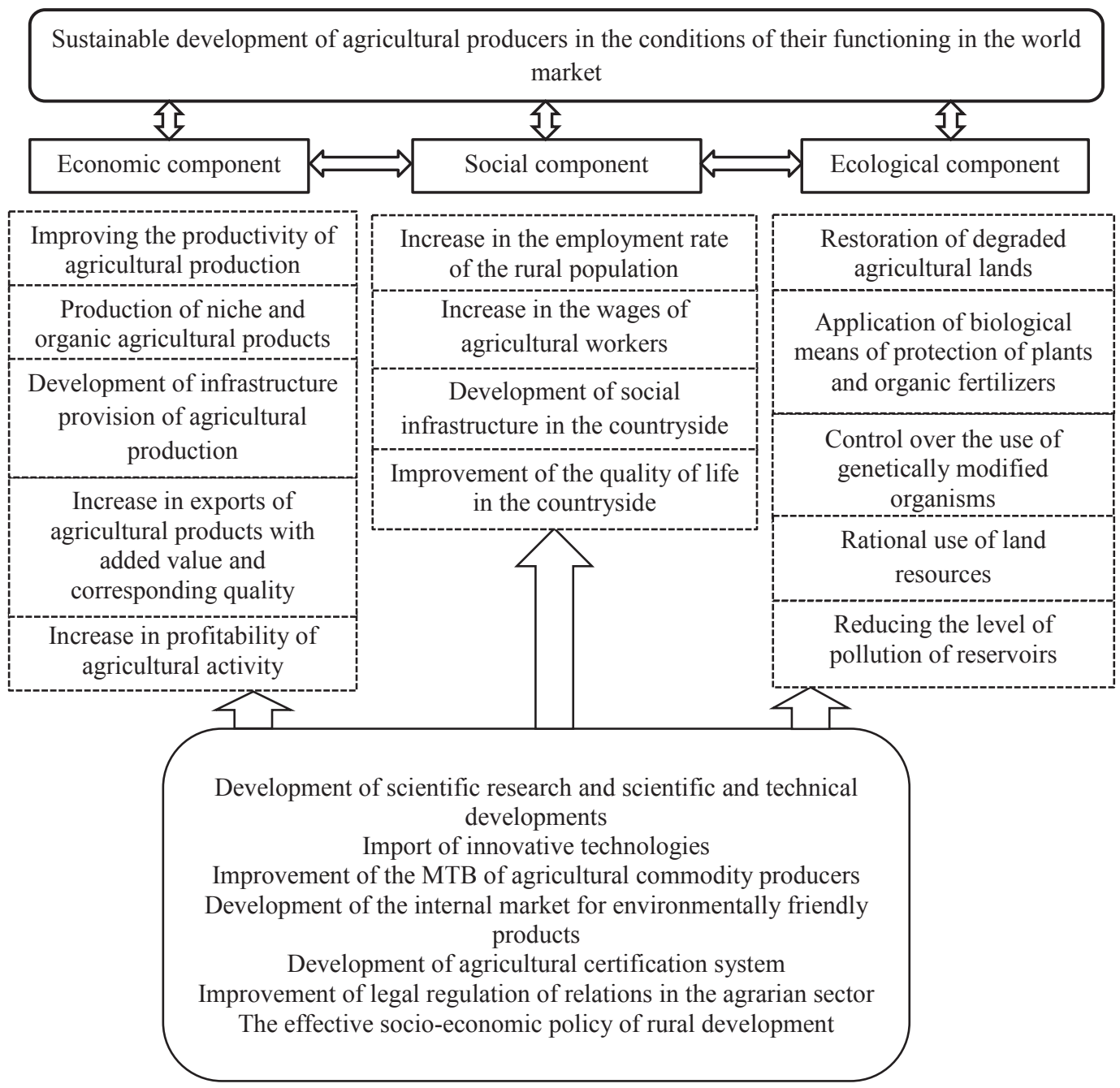

Figure 1. The system of sustainable development of agricultural producers in the conditions of their functioning in the world market

Source: the author's research

1.Improving the productivity of agricultural production. At present, in Ukraine, increasing productivity of agricultural production is achieved mainly through the use of quality seed materials, mineral fertilizers, and plant protection products. At the same time, the managerial, personnel, and technical components of productivity are often not taken into account.

In our opinion, the main components of the formation of productivity of agricultural production are not only available land resources, used seeds, fertilizers, and plant protection products. We believe that the greatest influence on the productivity of agricultural production is carried out by agronomy management of agricultural producers, the expediency of using certain agrotechnologies and their level of innovation, the presence of related systems in the production process (drying systems, cleaning of agricultural products, the possibility of delivering them with a minimum level of losses and capacity for its storage).
2. Production of niche and organic agricultural products.

Today, at agricultural enterprises of different sizes and forms of ownership, cultivating crops is predominantly subject to the conditions of the agricultural market, and economically attractive crops are grown, the realization of which makes it possible to obtain a stable profit. The production of monocultures (corn, rape, soybeans, grain crops) and saturation of field crop rotation with sunflower prevails, which leads to intensive use of nutrients from the soil harvesting complex and depletion of soils. Such a situation negatively affects not only the environment but also depletes the natural resources of the region, which in the long run may lead to a complete decline of rural areas. In such conditions, stimulation of the production of niche agricultural products at the regional level will contribute not only to solving economic and environmental problems in the activities of agricultural producers but also to improving 
the social component of rural development. In addition, the production of niche products is a priority direction for the agrarian sector of Ukraine, declared in the State Strategies $3+5$, aimed at strengthening the competitive advantages of small and medium-sized agricultural producers at the national and international levels. At the same time, it should be understood that the production of certain types of niche products should be directly proportional to the peculiarities of the regional conditions of agricultural activity and correspond to trends of development of world markets of niche types of agricultural products. In this context, in certain regions of Ukraine, it is appropriate to stimulate the production of organic agricultural products, honey, garlic, sorghum, walnuts, flax, mustard, raspberries and blackberries, beans, peas, and blueberries.

Organic farming is a sustainable form of agriculture that involves cost-effective resource management and has great potential for growth around the world. Numerous studies confirm that organic farming provides improved environmental and resource provision (land, water, etc.), protection of animals, climate, income situation for people employed in agriculture and, in general, for rural areas.

The official statistical surveys of the International Federation of Organic Agriculture Movements (IFOAM) confirm that in 2002, in Ukraine, there were registered 31 farms that received organic status, in 2017 there were already 430 certified organic farms, and the total area of certified organic agricultural land amounted to 423.5 thousand hectares.

Most Ukrainian organic farms are located in Odesa, Kherson, Kyiv, Poltava, Vinnytsia, Transcarpathian, Lviv, Ternopil, Zhytomyr regions. Ukrainian certified organic farms - of varying sizes - range from several hectares, as in most European countries, to several thousand hectares of arable land.

Studies of the Federation of the Organic Movement of Ukraine show that the modern domestic consumer market for organic products in Ukraine began to develop from the beginning of the 2000s, amounting to: 400 thousand Euros in 2006, 500 thousand Euros in 2007, 600 thousand Euros in 2008, 1.2 million Euros in 2009, 2.4 million Euros in 2010; this figure increased to 5.1 million Euros in 2011, to 7.9 million Euros in 2012, to 12.2 million Euros in 2013, to 14.5 million Euros in 2014, to 17.5 million Euros in 2015, and to 21.2 million Euros in 2016.

Due to favourable climatic conditions and fertile soils of Ukraine, local organic farming has great potential in global competition and offers additional prospects for the highly effective development of domestic agricultural producers. However, currently, Ukrainian agricultural producers predominantly produce organic raw materials for export. Development of the domestic market is still at its beginning, but it is already possible to recognize the tendency for positive development.
Spatial proximity to the EU export market and overcoming barriers to trade create an opportunity for foreign direct investment and the transfer of services and technologies. The modernization of agriculture and the improvement of working conditions associated with this will have a positive effect on the further development of the Ukrainian organic sector.

3. The development of infrastructure provision of agricultural production in the conditions of sustainable development of Ukrainian agriculture should be directed not only to increase of the production of this product but also to the creation of a comfortable social environment, a favourable psychological climate in the labour collective of the agricultural enterprise, the social motivation of labour. In addition, the production activity of agricultural producers must take into account the environmental situation in a particular region and be realized in such a way that not worsen the present state but improve it.

Currently, it is considered that enterprises producing agricultural machinery and equipment, mineral fertilizers, chemical ameliorants, seeds, and other materials for agriculture, research institutes form the production infrastructure of agriculture. At the same time, the most important are the research organizations and institutes that are developing: the latest technologies for the protection, reproduction, and enhancement of soil fertility; technical means of ecologically safe use of water resources; knowledge intensive technologies of organic crop production; resource-saving technologies of production of agricultural products, etc. In our opinion, the infrastructure support for the production of agricultural products, in addition to the above, should include the capacity for storing the produced products in a qualitative state for the longest period of time and at least educational and recreational facilities that will contribute to the improvement of the quality of labour resources of agricultural producers.

The development of infrastructure support for agricultural production at the present stage of development of our country is possible only if the efforts of the state and private sector with the international institutions are combined.

It has been established that almost all funds allocated from the public budget, provided by international donor countries, international organizations to the state or provided by international financial institutions on a commercial basis, in the context of the construction of infrastructure facilities, are directed mainly to the development of a system of elevator capacities, vegetable, and fruit storages. At the same time, in our opinion, the priority should be given to the development of research institutions that are potentially able to provide innovative agricultural development, to develop rural infrastructure, and to improve the environment. At the same time, if private enterprises receiving commercial loans themselves decide on the direction of the received 
funds, then the state must develop, present, and raise funds for the outlined projects for the development of infrastructure support for agricultural production. In the case of their successful realization, domestic agricultural producers will be able to improve their competitive advantages in the world market.

4. Increase in exports of agricultural products with added value.

The question of formation of added value in agriculture is rather controversial; politicians often speculate on it, scientists and practitioners argue. So, it is quite commonly believed that the added value in agriculture is the cost of processing raw materials and bringing them to a ready-to-use product. For example, grain - raw materials, flour - a product of the added value of raw materials "grain," bakery products a product of the added value of raw materials "flour" etc. In this context, the data of the State Statistics Service of Ukraine should be considered. The largest share in the commodity structure of exports of agricultural products and food industry in 2017 was made up of herbal products, mainly due to supplies of grain to foreign markets $-70.54 \%$. Fats and oils of vegetable or animal origin were exported in the amount of 4605.7 million UAH, with the basis of exports of sunflower oil - about $70 \%$. The finished food products accounted for $15.93 \%$ of the total export value. Based on the data presented and the abovementioned approach to the definition of added value in agriculture, we can state that, in fact, Ukrainian enterprises are predominantly exporters of products with no added value.

In addition to this thought, one should pay attention to the approach of Adam Smith and his followers, including P. Samuelson. Adam Smith, in his work, "Inquiry into the Nature and Causes of the Wealth of Nations," argued: "The cost added by the workers to the cost of materials is broken down by itself ... into two parts, one of which goes to pay their wages and the other to pay the profit of their entrepreneur for the entire capital, which he advanced in the form of materials and wages." Consequently, the added value consists of labour, profits, and taxes minus subsidies. The same added value is deducted by subtracting intermediate consumption from the total output.

According to the Public Council under the Ministry of Agrarian Policy and Food of Ukraine, the share of added value in the total output of agricultural products in 2016 amounted to $42.4 \%$, while in general in the Ukrainian economy the same indicator was only $37.6 \%$.

Consequently, Ukrainian enterprises mainly export agricultural products as raw materials, although they receive a higher share of added value in the production of agricultural products than in the overall economy of Ukraine. Therefore, it is partly possible to agree with the opinion that spacecrafts, rocket space complexes, and carrier rockets are the finished products for enterprises of the space industry of Ukraine, as well as bulls, dairy raw materials, grain of wheat or sunflower seeds are finished products for farm enterprises. At the same time, we believe that the urgent issues of the present in the activities of agricultural producers are the increase in production and sales (including the external market) of processed products. At the same time, it is not necessary to mix up the degree of depth of processing of agricultural products with its added value. Indeed, even deep sub-farm processing or production of food is equated and counted (added) to agricultural production, provided that the products are produced within the limits of one economic entity from their own agricultural raw materials.

It should be noted that the direction of activity of agricultural producers in the world market is formed, including, under the influence of demand and supply of certain types of agricultural products. Global demand for grain is much higher than world demand for flour, while global demand for sunflower oil is higher than global demand for sunflower seeds. Of course, it should be kept in mind that processed products are more expensive, and the process of processing is accompanied by the creation of new jobs; social development of territories where processing takes place; increase in revenues to budgets of different levels, etc. From this, when increasing exports, it is necessary to focus on increasing the level of the so-called added value, first of all, for those types of products that have a corresponding demand on the world market, can be produced and sold by small and medium-sized agricultural enterprises (products of vegetable growing, beekeeping, livestock farming, fruit and berry farming, etc.), create conditions for the socio-economic development of rural areas and minimize (or do not) pollute the environment. All this can be realized only with the support of the state (financial, regulatory), the influence of international and Ukrainian public organizations, raising the level of consciousness of agrarian business, the efforts of local settlement district and regional councils.

Thus, in order to increase the volume of agricultural production and its exports, a general improvement of the investment climate in the state and the investment attractiveness of agricultural enterprises is necessary; well-considered real support of the state is aimed at finding additional sources of financing for existing projects on the construction of processing facilities in rural areas with the input of raw materials of local agricultural enterprises and creation of favourable conditions for the search of markets for newly created products taking into account the state of food security of the country; effective cooperation of all stakeholders (state, public and business) to implement the most promising projects for the creation of added value of agricultural products in the conditions of sustainable development of agriculture in Ukraine.

5. Increase in profitability of agricultural activity in the conditions of sustainable development is possible 
due to increase in volumes of production and sales of manufactured products, diversification of agricultural activities with an orientation towards organic and niche agricultural products, reduction of the cost of production of agricultural products, restoration of parity pricing in the agro-industrial complex of Ukraine.

\section{Conclusions}

Sustainable development of agricultural producers in the conditions of their functioning in the world market can be achieved at the expense of: constant development of scientific research and scientific and technical developments in domestic agriculture, creation of favourable conditions for the implementation of foreign economic activity by agricultural commodity producers, including for the import of innovative agricultural technologies; improvement of the material and technical base of agricultural producers; development of the internal market for environmentally friendly products; improvement of the system of certification of agricultural production; improvement oflegal regulation of relations in the agrarian sector; realization of effective socio-economic policy of rural development. It is the effective fulfilment of the set tasks that will enable the formation of sustainable competitive advantages of agricultural producers in the world market and poses problems for further research by the author.

\section{References:}

Herasymiv, Z. M. (2016). Stalyi rozvytok silskoho hospodarstva [Sustainable development of agriculture]. Ahrosvit, 9, 16-19. (in Ukrainian)

Kovalchuk, S. Ia. (2017). Vplyv hlobalizatsiinykh protsesiv na rozvytok silskykh terytorii u konteksti selozberihaiuchoi modeli ahrarnoho pidpryiemnytstva [Influence of globalization processes on the development of rural areas in the context of the village-saving model of agrarian entrepreneurship]. Ekonomika $i$ suspilstvo, 8, 52-58. (in Ukrainian)

Khristian Novak, Dr. Yokhannes Kotchi (Eds.). (2016). Orhanichne silske hospodarstvo dosvid Nimechchyny mozhlyvosti dii dlia Ukrainy: Zvit z ahrarnoi polityky [Organic Farming Experience of Germany - Opportunities for Ukraine: Agrarian Policy Report]. Proekt «Nimetsko-ukrainskyi ahropolitychnyi dialoh». Kyiv. (in Ukrainian) Orhanik v Ukraini [Organic in Ukraine]. Federatsiia orhanichnoho rukhu Ukrainy. Retrieved from: http://www.organic.com.ua/uk/homepage/2010-01-26-13-42-29 (in Ukrainian)

Sabluk, V. (2017). Yak «vyrostyty» dodanu vartist v APK [How to "grow" added value in the agroindustrial complex]. Agropolit.com: hariacha ahropolityka. Retrieved from: https://agropolit.com/blog/123-yak-virostitidodanu-vartist-v-apk (in Ukrainian)

Sait orhanizatsii "Mizhnarodna Federatsiia orhanichnoho silskohospodarskoho rukhu" [Site organization International Federation of organic agricultural movement]. Retrieved from: https://www.ifoam.bio/en. (in Ukrainian)

Tovarna struktura zovnishnoi torhivli u 2017 rotsi (2018). [Commodity structure of foreign trade in 2017] Derzhavna sluzhba statystyky Ukrainy. Retrieved from: http://www.ukrstat.gov.ua/

Tsili staloho rozvytku: Ukraina. Natsionalna dopovid (2016). [Sustainable Development Goals: Ukraine. National report]. Kyiv: Ministerstvo ekonomichnoho rozvytku i torhivli. (in Ukrainian)

Uzhva, A. M. (2015). Formuvannia staloho rozvytku silskoho hospodarstva: zarubizhnyi dosid [Formation of sustainable development of agriculture: foreign experience]. Naukovyi visnyk uzhhorodskoho natsionalnoho universytetu. Seriia: Mizhnarodni ekonomichni vidnosyny ta svitove hospodarstvo, 5, 174-176. (in Ukrainian)

Yaroslavskyi, O. (2017). Dodana vartist u silskomu hospodarstvi. Formuvannia ta rozpodil [Added value in agriculture. Formation and distribution]. Ahroportal. Retrieved from: http://agroportal.ua/ua/views/blogs/ dobavlennaya-stoimost-v-selskom-khozyaistve-formirovanie-i-raspredelenie/ (in Ukrainian) 